E. А. Ботоева, Л. М. Жовтун, А. Н. Нечунаева. Методы обучения на кафедре акушерства и гинекологии

УДК 618.1

DOI: $10.18101 / 2306-1995-2019-1-49-52$

\title{
МЕТОДЫ ОБУЧЕНИЯ НА КАФЕДРЕ АКУШЕРСТВА И ГИНЕКОЛОГИИ
}

\author{
(С Ботоева Елена Аполлоновна \\ кандидат медицинских наук, доцент, \\ Бурятский государственный университет им. Д. Банзарова \\ Россия, Улан-Удэ, 670002, ул. Октябрьская, 36а \\ E-mail: elenabotoeva@list.ru

\section{(C) Жовтун Людмила Марковна} \\ старший преподаватель, \\ Бурятский государственный университет им. Д. Банзарова \\ Россия, Улан-Удэ, 670002, ул. Октябрьская, 36а \\ E-mail: elenabotoeva@list.ru \\ (C) Нечунаева Александра Николаевна \\ преподаватель, \\ Бурятский государственный университет им. Д. Банзарова \\ Россия, Улан-Удэ, 670002, ул. Октябрьская, 36а \\ E-mail: alexandra907@mail.ru
}

В настоящее время сложно представить процесс обучения без применения как традиционных, так и инновационных подходов в изучении акушерства Объединение педагогических технологий в процессе позволяет повысить результативность обучения. Для профессиональной подготовки студентов используется одна из форм активного обучения, такое как контекстное обучение. Основная его идея заключается в максимальном приближении обучающихся к будущей профессиональной деятельности. Данная методика реализуется путем установки на тимбилдинг внутри группы, индивидуальную помощь обучающимся, совместную деятельность с преподавателем, а также характеризуется открытостью к обмену мнениями среди участников. Следует сделать особый акцент на поэтапном переходе к базовым формам деятельности: от учебной к профессиональной деятельности (деловые и дидактические игры) к учебно-профессиональной деятельности (НИРС, практики, стажировки).

Ключевые слова: активное обучение, студент, преподаватель, акушерство и гинекология, самообучение.

Для цитирования:

Ботоева Е. А., Жовтун Л. М., Нечунаева А. Н. Методы обучения на кафедре акушерства и гинекологии // Вестник Бурятского государственного университета. Медицина и фармация. 2019. Вып. 1. С. 49-52.

В плане организаций занятий на кафедре акушерства и гинекологии с курсом педиатрии ФГБОУ ВО «БГУ» внедряется технология управляемого самообучения студентов. Основной характеристикой этой технологии является возможность максимально активизировать личностный потенциал обучающихся. Главная задача преподавателя заключается в построении такого образовательного процесса, в котором на первое место выходила бы субъектная позиция обучающегося, обозначились бы его индивидуальные образовательные предпочтения. Преподаватель же перестает быть для студентов транслятором готовых знаний. 
Он управляет учебным процессом, корректирует и координирует деятельность студентов и сам становится участником познавательного взаимодействия. При этом преподаватель выполняет функцию менеджера учебного процесса, активизирующего, направляющего и перенаправляющего потоки учебной информации и действий. В этом и есть суть технологии управляемого самообучения студентов.

Одна из главных задач для преподавателя является воссоздание такого образовательного процесса, в котором субъектная позиция обучающегося играла бы значительную роль, а так же чтобы личный образовательный выбор студента был важным фактором при подходе к обучению. При этом сам преподаватель прекращает быть для студентов транслятором готовых знаний и выходит в роли управляющего учебным процессом, - корректирует и координирует деятельность студентов, становясь участником познавательного взаимодействия. Как менеджер учебного процесса, преподаватель активизирует и направляет потоки учебной информации. В этом и заключается методика управляемого самообучения студентов.

Современный процесс обучения должен основываться также на создании условий для формирования общекультурных и профессиональных компетенций, активного творческого подхода к своей будущей профессии.

Недостаточная практическая подготовка может быть частично компенсирована в процессе так называемой «деловой игры». Деловая игра является воссозданием рабочего процесса, упрощенным моделированием производственной ситуации. Участникам игры необходимо выполнить определенный алгоритм, с помощью которого они могли бы достичь желаемого результата. В сценарии должны быть заранее прописаны правила игры. Включение деловых игр в процесс обучения развивает аналитические способности и профессиональные компетенции студентов, а так же помогает интерпретировать полученную информацию, аргументированно отстаивать свое мнение и работать в команде. Образовательная функция деловой игры очень значима, поскольку «...деловая игра позволяет задать в обучении предметный и социальный контексты будущей профессиональной деятельности и тем самым смоделировать более адекватные по сравнению с традиционным обучением условия формирования личности специалиста...»

В этом случае осуществляется детальный разбор проблемной ситуационной задачи. Для полноценного участия в игре требуется адекватная теоретическая подготовка, без которой игра становится непродуктивной. Командная игра вовлекает всех участников учебного процесса, например: первый студент исполняет роль больного, второй - врача бригады «Скорой помощи», привлекаются консультанты и другие специалисты. Таким путем преподаватель может в краткие сроки оценить уровень интеллекта и степень обучаемости конкретного студента. Включение деловых игр и других форм активного взаимодействия в процесс обучения позволяет за ограниченный период времени улучшить усвоение, оптимизировать учебный процесс, развить способность принимать решения, навыки клинического мышления.

Для лучшего учебного процесса по преподаванию дисциплины акушерство и гинекологии на кафедре новые методы обучения, в которые входят:

1. Создание электронного курса обучения по акушерству и гинекологии. В этот курс входят теоретическая информация по дисциплине, видеоматериалы по 
некоторым практическим навыкам. Это предоставляет студентам возможность для неоднократного повторения теоретической части материала, а также практических навыков. Также в электронный курс входят задания для студентов, такие как создание презентаций, кроссвордов, решение тестового контроля, создание ментальных картсоздание инфографики. Схематическое изложение материала позволяет более быстрому запоминанию и воспроизведению в дальнейшем.

2. Создание презентации со звуковым сопровождением.

3. Внедрение в процесс изучения игровых форм обучения (деловые и ролевые игры, обсуждение проблемной ситуации, создание учебных консилиумов врачей).

Внедрение электронного метода обучения дает следующие преимущества:

- непрерывный контроль качества знаний,

- объективная оценка студентов,

- минимизирование вероятности коррупции,

- автоматизация административных структур (определение статуса, подготовка справок, документов).

Основными принципами в системе обучения MOODLE являются:

- Все участники процесса, включая преподавателей, постоянно обучаются.

- Лучший способ изучения - возможность обучить других людей полученными знаниями.

- Большое положительное влияние оказывает возможность наблюдения за деятельностью коллег.

- Понимание других людей.

- Создание гибкой учебной среды.

Использование системы MOODLE позволяет:

- Большое количество возможных вариантов предоставления информации.

- Интерактивность обучения.

- Возможность многократного изучения материала.

- Структурирование и модульность контента.

- Создание удобной справочной системы.

- Самоконтроль.

- Выстраивание индивидуальных образовательных траекторий.

- Конфиденциальность.

- Соответствие принципам успешного обучения.

Нельзя никак исключать и традиционные методы образования. Это практическая работа в родильном отделении. Студенты проводят обследование беременных. С учетом полученных данных составляют план ведения, лечения. Каждый студент оформляет истории родов. Также студентам рекомендуется посещать в родильном доме дежурства. Наблюдение за ведением родов, операций позволяют постичь практические нюансы, использовать их в своей практике.

Таким образом, сочетание педагогических приемов в процессе обучения способствует более активному становлению студентов, дает мотивацию для того, чтобы стать высококвалифицированным специалистом, делая их более адаптированными в современном обществе и социально значимыми.

Литература

1. Алехин А. Ю. Общие методы обучения в школе. Киев: Радянська школа, 1983. $244 \mathrm{c}$. 
2. Давыдов В. В. Теория развивающего обучения. М.: ИНТОР, 1996. 544 с.

3. Загвязинский В. И. Теория обучения: современная интерпретация: учеб. пособие для вузов. 3-е изд., испр. М.: Академия, 2006. 192 с.

4. Краевский В. В., Хуторской А. В. Основы обучения: дидактика и методика: учеб. пособие для студ. высш. учеб. завед. М.: Академия, 2007. 352 с.

5. Ляудис В. Я. Методика преподавания психологии: учеб. пособие. 3-е изд., испр. и доп. М.: Изд-во УРАО, 2000. 128 с.

6. Михайличенко О. В. Методика преподавания общественных дисциплин в высшей школе: учеб. пособие. Сумы: СумДПУ, 2009. 122 с.

\title{
TRAINING METHODS AT THE DEPARTMENT OF OBSTETRICS AND GYNECOLOGY
}

\author{
Elena A. Botoeva \\ Candidate of Medical Sciences, Associate Professor \\ Dorzhi Banzarov Buryat State University \\ 36a Oktyabrskaya st, Ulan-Ude, 670002, Russia \\ E-mail: elenabotoeva@list.ru \\ Lyudmila M. Zhovtun \\ Senior Lecturer \\ Dorzhi Banzarov Buryat State University \\ 36a Oktyabrskaya st, Ulan-Ude, 670002, Russia \\ E-mail: elenabotoeva@list.ru \\ Aleksandra N. Nechunaeva \\ Teacher \\ Dorzhi Banzarov Buryat State University \\ 36a Oktyabrskaya st, Ulan-Ude, 670002, Russia \\ E-mail: alexandra907@mail.ru
}

At present, it is difficult to imagine the learning process without using both traditional and innovative approaches in the study of obstetrics. Implementing pedagogical technologies in the process allows increasing the effectiveness of training. One of the forms of active learning is used for the training of students, such as contextual learning. Its main idea is to maximize the approximation of students to future professional activities. This technique is implemented by setting up team building within the group, individual assistance to students, joint activities with the teacher, and is also characterized by openness to the exchange of views among participants. Particular emphasis should be placed on a phased transition to the basic forms of activity: from academic to professional activities (business and didactic games) to educational and professional activities (research, practice, internships).

Keywords: active training, student, teacher, obstetrics and gynecology, self-education. 